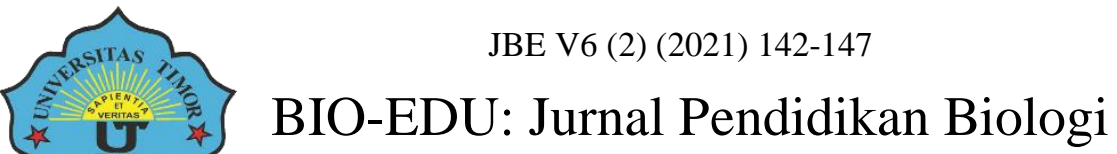

https://jurnal.unimor.ac.id/JBE/index

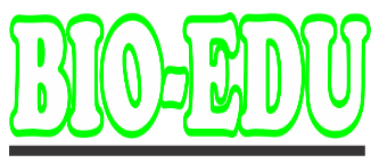

Jurnal Pendidikan Biologi

\section{Seleksi Cekaman Kekeringan Secara In Vitro Tunas Jagung Putih (Zea mays L.) Menggunakan PEG}

\author{
Maria Yustiningsih ${ }^{1}$, Amanda Poto ${ }^{1}$, Ludgardis Ledheng ${ }^{1}$ \\ ${ }^{1}$ Prodi Pendidikan Biologi Universitas Timor \\ Email: yyustiningsih@gmail.com
}

DOI: https://doi.org/10.32938/jbe.v6i2.1521

\begin{abstract}
Abstrak
Penelitian ini bertujuan untuk mengidentifikasi respon pertumbuhan eksplan tunas jagung putih (Zea mays L.) pada seleksi cekaman kekeringan menggunakan Polyethylene glicol (PEG) secara in vitro. Penelitian dilakukan di Laboratorium Pendidikan Biologi Universitas Timor menggunakan desain Rancangan Acak Lengkap (RAL) dengan tiga perlakuan konsentrasi PEG yaitu PEG 0 gr/L (kontrol), PEG 5 gr/L, dan 15 gr/L yang diberikan secara bertahap. Eksplan yang digunakan adalah eksplan tunas jagung putih yang ditumbuhkan pada media basal Murashige\&Skoog (MS) dengan PEG sesuai konsentrasi perlakuan. Parameter yang diamati adalah panjang akar, tinggi tunas dan biomassa tanaman untuk melihat respon tanaman terhadap cekaman kekeringan. Data dianalisis menggunakan SPSS dan uji lanjut menggunakan DMRT. Hasil penelitian menunjukkan bahwa konsentrasi PEG yang diberikan secara bertahap dapat mempengaruhi pertumbuhan tanaman khususnya tinggi tunas. Perlakuan PEG $5 \mathrm{gr} / \mathrm{ml} \mathrm{dan} 15 \mathrm{gr} / \mathrm{ml}$ merupakan pertumbuhan tunas paling tinggi $(2,625 \mathrm{~cm})$ bila dibandingkan PEG $0 \mathrm{gr} / \mathrm{L}(1,47)$ yang mengindikasikan eksplan masih dapat tumbuh pada kondisi cekaman kekeringan. Meskipun demikian kedua perlakuan menunjukkan tidak adanya pengaruh PEG terhadap panjang akar dan biomassa yang dapat mengindikasikan adanya penghambatan pertumbuhan pada perlakuan yang diberikan. Berdasarkan hasil penelitian dapat disimpulkan bahwa perlakuan PEG dapat mempengaruhi laju pertumbuhan tunas jagung putih dan penghambatan pertumbuhan.
\end{abstract}

Kata kunci : "Cekaman kekeringan"; "kultur jaringan”; "PEG'; "seleksi in vitro"

\begin{abstract}
This study aims to identify the morphology response of white corn (Zea mays L) shoots explant on in vitro drought stress selection using Polyethylene glycol (PEG). The study was conducted at the Biology Education Laboratory, University of Timor using a Completely Randomized Design (CRD) with three treatment concentrations of PEG, namely PEG 0 gr/L (control), PEG $5 \mathrm{gr} / \mathrm{L}$, and $15 \mathrm{gr} / \mathrm{L}$. The explants grown on Murashige \& Skoog (MS) basal media with PEG according to the treatment concentration. Parameters observed were root length, shoot height and plant biomass to see plant response to drought stress. Data were analyzed using SPSS and further test using DMRT. The results showed that the concentration of PEG gradually could affect plant growth, especially shoot height. PEG concentration of 5 $\mathrm{gr} / \mathrm{ml}$ and $15 \mathrm{gr} / \mathrm{ml}$ was the highest shoot growth $(2,625 \mathrm{~cm})$ when compared to PEG $0 \mathrm{gr} / \mathrm{L}(1.47)$ which indicated that explants could still grow under drought stress conditions. However, both treatments showed no effect of PEG on root length and biomass which could indicate growth inhibition in the given selection. Based on the results it can be concluded that PEG selection can affect the growth rate of white corn shoots and growth inhibition.
\end{abstract}

Keywords: "drought stress", plant tissue culture"; "PEG"; "in vitro selection" 


\section{PENDAHULUAN}

Jagung (Zea mays L.) merupakan komoditas strategis setelah padi bagi sebagian penduduk Indonesia. Jagung memiliki banyak manfaat untuk kesehatan tubuh yakni jagung mengandung vitamin B12 untuk mencegah anemia, zat besi, kaya akan antioksidan yang mampu melawan radikal bebas penyebab kanker, dan kaya akan serat, baik serat larut dan tidak larut yang baik untuk pencernaan (Tysara, 2020). Di Provinsi Nusa Tenggara Timur (NTT), khususnya di Kabupaten Timor Tengah Utara (TTU), jagung merupakan makanan pokok. Jenis jagung yang dijadikan makanan pokok adalah diantaranya adalah jenis jagung putih (Zea mays L.). Berdasarkan Data Produksi Tanaman Pangan tahun 2010 sampai dengan 2018 dari Dinas Pertanian Kabupaten Timor Tengah Utara (TTU), produktivitas jagung secara umum adalah 72.145 ton dengan luas lahan penanaman 21,408. Jika dibandingkan dengan produktivitas jagung dan luasnya lahan maka dapat diketahui bahwa hasil dari produktivitas jagung di Kabupaten TTU per tahun tidak seimbang dengan kebutuhan penduduk (Dinas Pertanian, 2019). Salah satu penyebab rendahnya produktivitas jagung adalah kondisi iklim dan curah hujan yang pendek yang terjadi di sebagian besar wilayah TTU. Sesuai data Badan Pusat Statistik (BPS) Kabupaten TTU tahun 2018, curah hujan rata-rata di TTU $1506 \mathrm{~mm}$ dan rata-rata hujan 73 hari per tahun (BPS, 2018). Dengan jumlah tersebut, tanaman hortikultura seperti jagung tidak dapat tumbuh secara optimum karena kapasitas air tidak memenuhi kebutuhan dalam pertumbuhan jagung atau tanaman mengalami cekaman kekeringan.

Cekaman kekeringan sangat berdampak pada setiap fase pertumbuhan jagung, khususnya pada fase perkecambahan dan fase vegetatif dimana pada fase ini tanaman membutuhan kapasitas air yang banyak. Kekurangan air pada fase ini selain mempengaruhi pertumbuhan tanaman secara keseluruhan juga akan mempengaruhi produktivitas tanaman jagung (Sammons et al., 1980; Kramer, 1980).

Salah satu cara yang digunakan untuk mengatasi cekaman kekeringan adalah dengan melakukan screening atau seleksi secara in vitro untuk menghasilkan tanaman yang tahan terhadap cekaman lingkungan dengan cara memberikan agen penyeleksi ke dalam media. Polyethylene glicol (PEG) adalah salah satu senyawa non toxic yang dapat digunakan untuk seleksi cekaman kekeringan karena PEG menciptakan potensial osmotik yang setara dengan kondisi tanah kapasitas lapang dan titik kelembaban kritis sehingga tanaman dikondisikan mengalami cekaman kekeringan. Penelitian Badami (2009) menyatakan bahwa dengan penambahan PEG secara bertahap pada media dapat menginduksi adaptasi sel dan jaringan sehingga tanaman dapat beradaptasi pada cekaman lingkungan. Lebih lanjut menurut Amzeri (2011) yang telah melakukan penelitian secara in vitro mengetahui bahwa PEG dapat menginduksi respon tanaman terhadap cekaman kekeringan dengan memperlambat pertumbuhan dan mengeluarkan senyawa osmoregulator. Penelitian ini bertujuan untuk mengidentifikasi respon morfologi pertumbuhan tanaman jagung putih (Zea mays L.) pada seleksi cekaman kekeringan menggunakan Polyethylene glicol (PEG) secara in vitro. Penelitian diharapkan dapat memberikan informasi mengenai potensi pengembangan tanaman yang tahan terhadap cekaman kekeringan sehingga selain dapat meningkatkan produktivitasnya juga dapat melestarikan plasma nutfah jagung dan melestarikan makanan pokok masyarakat Nusa Tenggara Timur dan Kabupaten Timor Tengah Utara.

\section{METODE}

Penelitian ini dilaksanakan di Laboratorium Pendidikan Biologi Universitas Timor pada bulan September sampai November 2020. Penelitian dilakukan menggunakan 
desain Rancangan Acak Lengkap (RAL) dengan tiga perlakuan konsentrasi PEG yang diberikan secara bertahap yaitu konsentrasi PEG $0 \mathrm{gr} / \mathrm{L}, 5 \mathrm{gr} / \mathrm{L}$, dan $15 \mathrm{gr} / \mathrm{L}$. Eksplan yang digunakan adalah eksplan dari biji jagung putih yang ditumbuhkan pada media basal Murashige\&Skoog (MS) dengan penambahan PEG sesuai dengan perlakuan.

Penelitian dilakukan melalui 2 tahap yaitu inisiasi dan seleksi eksplan tanaman jagung. Tahapan inisiasi diawali dengan sterilisasi alat dan media dengan menggunakan autoklaf pada suhu $121^{\circ} \mathrm{C}$ selama 15 menit; sedangkan sterilisasi eksplan dimulai dengan pencucian eksplan pada air mengalir $\pm 10-15$ menit dan dikeringkan dengan kertas saring. Eksplan selanjutnya direndam dalam alkohol $70 \%$ selama 1 menit dan dicuci dalam akuades steril dilanjutkan dengan perendaman menggunakan $\mathrm{NaOCl} 4 \%$ selama 10 menit. Eksplan dicuci berulang (3-5 kali) menggunakan akudes steril dan dikeringkan menggunakan kertas saring. Perlakuan sterilisasi diulang kembali di ruangan steril menggunakan laminar atau biosafety cabinet agar eksplan benar-benar steril. Eksplan steril kemudian ditanam pada media basal MS dan diamati sampai pertumbuhan tunas awal selama 1-2 minggu. Tahapan seleksi dilakukan dengan memindahkan eksplan yang berukuran sama ke dalam media PEG secara bertahap dimulai dari PEG $0 \mathrm{gr} / \mathrm{L}$. Setelah periode pertumbuhan tunas (1-2) minggu maka tanaman dipindahan ke media lanjutan PEG $5 \mathrm{gr} / \mathrm{L}$ dan PEG $15 \mathrm{gr} / \mathrm{L}$ dan diamati sampai terjadinya penambahan pertumbuhan yang mengindikasikan tanaman dapat tumbuh dan beradaptasi pada media yang diberikan.

\section{HASIL DAN PEMBAHASAN}

Seleksi atau screening tanaman merupakan kegiatan agronomi yang telah ada sejak manusia mulai membudidayakan tanaman dengan tujuan pemuliaan tanaman. Seleksi in vitro merupakan salah satu cara penyaringan yang dianggap lebih efektif dan efiesien (Jesicca et al., 2018). Pada penelitian ini seleksi in vitro dilakukan menggunakan PEG secara bertahap dan diketahui bahwa PEG memberikan pengaruh bervariasi pada pertumbuhan tanaman jagung yang hasil selengkapnya seperti tampak pada tabel 1 .

Tabel 1. Pengaruh PEG pada pertumbuhan tanaman

\begin{tabular}{|l|c|c|c|}
\hline \multicolumn{1}{|c|}{ Perlakuan } & $\begin{array}{c}\text { Panjang Akar } \\
(\mathrm{cm})\end{array}$ & $\begin{array}{c}\text { Tinggi Tunas } \\
(\mathrm{cm})\end{array}$ & $\begin{array}{c}\text { Biomassa } \\
\text { Tanaman }(\mathrm{gr})\end{array}$ \\
\hline Media PEG 0 gr/ml & $4,125 \pm 0,507^{\mathbf{b}}$ & $1,475 \pm 0,303^{\mathbf{b}}$ & $0,535 \pm 0,182^{\mathbf{b}}$ \\
\hline Media PEG 5 gr/ml & $3,225 \pm 0,448^{\mathbf{b}}$ & $2,625 \pm 0,405^{\mathbf{a}}$ & $0,700 \pm 0,209^{\mathbf{b}}$ \\
\hline Media PEG 15 gr/ml & $3,225 \pm 0,448^{\mathbf{b}}$ & $2,625 \pm 0,405^{\mathbf{a}}$ & $0,610 \pm 0,195^{\mathbf{b}}$ \\
\hline
\end{tabular}

Keterangan: Angka yang diikuti huruf yang sama pada kolom yang sama menunjukkan hasil yang tidak berbeda nyata pada uji DMRT $5 \%(\alpha=0,05)$

Berdasarkan tabel diatas diketahui bahwa PEG $5 \mathrm{gr} / \mathrm{L}$ dan $15 \mathrm{gr} / \mathrm{L}$ berpengaruh nyata pada pertumbuhan tunas dan tidak berpengaruh pada biomassa dan panjang akar tanaman. Pada dua perlakuan ini atau seleksi tahap kedua dan ketiga, biomassa dan akar tanaman tidak mengalami penambahan pertumbuhan (berat dan panjang) secara signifikan diduga karena adanya penghambatan pertumbuhan yang disebabkan oleh perlakuan PEG. Menurut Kaswan (2009), kondisi selektif akibat penambahan PEG dalam media dapat bersifat menghambat pertumbuhan dan perkembangan sel/jaringan yang peka. Dengan seleksi secara bertahap, sel/jaringan varian yang toleran dapat berkembang normal yang sedangkan bagian yang peka akan terhambat dan berhenti mengalami 
pertumbuhan bahkan akan mengalami kematian. Kondisi ini juga sesuai dengan hasil penelitian yang dilakukan dimana pada interval pengamatan satu minggu, eksplan dapat bertunas dan berkembang ditandai dengan terbuka koleoptil sehingga muncul daun pertama yang menggulung berwarna hijau. Namun seiring dengan peningkatan konsentrasi seleksi PEG hanya pertumbuhan tunas yang bertambah tinggi sedangkan bagian tanaman lain mengalami penghambatan pertumbuhan. Gambar 1 dibawah ini menunjukkan perbandingan pertumbuhan tunas yang diberikan perlakuan seleksi cekaman kekeringan menggunakan PEG secara bertahap.

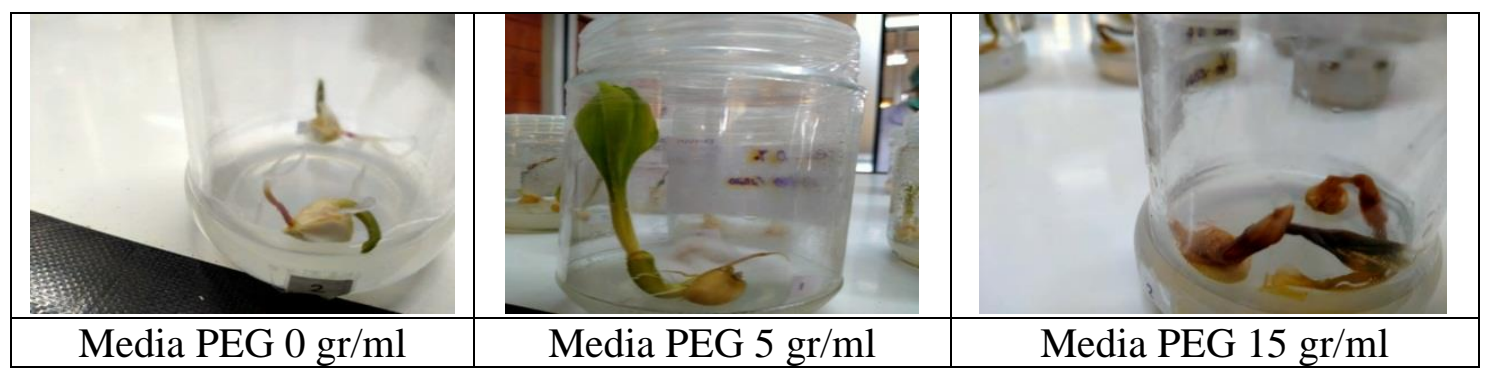

Gambar 1. Pengaruh Seleksi cekaman kekeringan menggunakan PEG pada pertumbuhan eksplan tunas jagung putih (Zea mays L.)

PEG adalah senyawa kimia yang mampu meningkatkan tekanan osmotik pada akar tumbuhan serta menyebabkan penurunan potensial air serhingga akan mensimulasikan bahwa suatu tanaman sedang mengalami cekaman kekeringan. PEG dengan kisaran berat molekur 4000 - 6000 dapat menciptakan potensial osmotik setara dengan kondisi kapasitas tanah dan titik kelembaban kritis sehingga eksplan memberikan respon yang sama dengan tanaman yang mengalami cekaman di lapangan (Rahayu et al., 2005). Penggunaan PEG 6000 pada penelitian ini memberikan respon yang hampir sama pada tanaman dimana pada seleksi ketiga (PEG 15g/L), tanaman tidak dapat toleran terhadap kekeringan yang ditandai dengan beberapa plantlet yang mulai menguning dan berlubang serta mengalami perubahan warna dari kekuningan menjadi kecoklatan kemudian daunnya melayu hingga akhirnya mati pada akhir periode pengkulturan. Pada kondisi cekaman kekeringan, tanaman jagung putih mengalami kelayuan dan penggulungan daun yang merupakan gejala kritis tanaman dan defisit air dimana laju kehilangan air melalui tanspirasi lebih besar dibandingkan laju absorbsi air oleh akar (Banzinger, 2000).

\section{KESIMPULAN DAN SARAN Kesimpulan}

1. Seleksi cekaman kekeringan menggunakan PEG dapat mempengaruhi pertumbuhan tunas tanaman jagung

2. Planlet tanaman jagung putih tidak mampu tumbuh pada konsentrasi seleksi PEG $15 \mathrm{~g} / \mathrm{L}$

\section{Saran}

Diperlukan penelitian lanjutan untuk mengindentifikasi perubahan fisiologis dan ketahanan tanaman jagung putih pada cekaman kekeringan

\section{DAFTAR RUJUKAN}

Badami, K., \& Amzeri. A. (2009). Seleksi In Vitro untuk Toleransi Terhadap Kekeringan pada Jagung (Zea mays L.) dengan Polyethylene Glycol (PEG). Agrovigor, 84. 
Banzinger, M. a. (2000). Breeding for drought tolerance intropical maize - conventional approach and challenges to molecularapproaches, In Ribaut, J.-M and D. Poland (ed.s) Molecular approaches forthe genetic improvement of cereals for stable production in water limitedenviroments. Stategic planning workshop held at CIMMYT EL Batan, Mexico 21-25 June 1999, 69-72.

Badan Pusat Statistik, Kabupaten. TTU. (2018). Kabupaten Timor Tengah Utara Dalam Rangka Timor Tengah Utara Regency in Figures. Kefamenanu: BPS Kabupaten Timor Tengah Utara.

Dinas Pertanian. (2019). Data Produksi Tanaman Pangan Di Kabupaten TTU. Kefamenanu.

George, E. F. dan P. Sherrington. (1984). Plant propagation by tissue culture. Hand Book and Directory of Comereial Laboratories. Eastern Press, Reading, Berks. England.

Hu, C. Y. dan P. J. Wang. (1983). Meristem Shoot Tip and Bud Cultures. Di dalam: Ammirato PV, Yamada Y, editor. Handbook of Plant Cell Culture: Techniques for Propagation and Breeding. Volume ke-1. Mc Millan Publ. Co. London.

Hussey ,G. and Stancey, N.J. (1981). In vitro propagation of potato (Solanum tuberosum L) . Annals of Botany. $48 ; 787-796$.

Jesicca, Netty, W., dan Devianty. (2018). Kultur Jaringan. Yogyakarta: ANDI Yogyakarta.

Kramer, P. J. (1980). Drought, Stress and the Origin of Adaptation. In : Turner, N. C., and P. J. Kramer. Adaptation of plants Water and High Temperature Stress. John Willey and Sons, Inc. New York.

Mellor, F.C. and Stance Smith,R. (1967). Eradication of virus X, thermotheraphy. Phytophathology, 57; 674-678.

Mexal, J. J.T Fisher., Osteryoung, J., and Reid, P. C. P. (1975). Oxygen Aviability In Polyetylena Glycol Solution And Its Complication Plant Water Relation. Plant Physiol.

Mudmainah, S. (2017). Sintesis Selulosa-Poli Etilen Glikol (Peg) Dan Aplikasinya Dalam Sistem Pelepasan Obat Ibuprofen., (hal. 11-13).

Nuning, A. S., Syafrudin., Sri, R. E. S. (2004). Fase Perkecambahan Dan Pertumbuhan Tanaman Jagung. Balai Penelitian Tanaman Serealia, Maros.

Purwono, D. R. (2005). Bertanaman Jagung Unggul. Penerbit Swaday Jakarta.

Rahayu, E. S., Guhardja, E., Ilyas, S., Sudarsono. (2005). Polietilenena glikol (PEG) dalam media in vitro menyebabkan kondisi cekaman yang menghambat tunas kacang tanah (Arachis hypogaea L.). Hayati (11): 39-48.

Rifqi, A. (2016, Oktober 06). Dipetik Januari 23, 2020, dari Istilah Kultur Jaringan: http://id.scribd.com/document/326585567/Pengertian-Eksplan-AdalahPotongan.

Sammons, D. J., D. B. Peters and T. Hymowitz. (1980). Screening soybeans for tolerance to moisture stress: a field procedure. Filed Crops Res. 3:321-335. 
Sinaga, E., M. S. (2015, april). Seleksi Toleransi Kekeringan In Vitro terhadap Enam Belas Aksesi Tanaman Terung (Solanum melongena L.) dengan Polietilene Glikol (PEG). 21.

Tysara, L. (2020, September 20). 10 Manfaat Jagung Rebus Untuk Kesehatan yang Jarang Diketahui. Retrieved from http://m.liputan6.com/hot/read/4359555/10manfaat-jagung-rebus-untuk-kesehatan-yang-jarang-diketahui. 